\title{
Pengaruh Daging Ikan Lemadang terhadap Mutu Keripik Ubi Kayu (Manihot Utilisima)
}

\author{
Effect of Lemur Fish Meat \\ to Quality of Cassava Chips (Manihot Utilisima) \\ Angcivioletta Moniharapon ${ }^{1}$ \\ ${ }^{1}$ Peneliti Balai Riset dan Standardisasi Industri Manado \\ e-mail: Moniharaponletta@yahoo.co.id
}

\begin{abstract}
ABSTRAK
Kandungan zat gizi yang paling banyak dalam ubi kayu adalah karbohidrat. Keripik sebagai salah satu produk pangan yang diolah melalui proses penggorengan rendam memiliki kerenyahan sebagai karakteristik tekstur yang penting untuk dikontrol. Metode penelitian bersifat deskriptif dengan uji kimia dan uji organoleptik. Tujuan dari penelitian ini adalah mempelajari penambahan daging ikan lemadang pada mutu keripik ubi kayu. Hasil penelitian menyatakan bahwa tingginya kadar air akan mempengaruhi warna, tekstur dan rasa keripik ubi kayu, tingginya kadar abu mempengaruhi nilai tekstur renyah keripik ubi kayu, tingginya kadar asam lemak bebas (FFA) berpengaruh pada rasa dari keripik ubi kayu.

Kata Kunci: ubi kayu, uji kimia, uji organoleptik
\end{abstract}

\section{ABSTRACT}

The most nutrient content in cassava is carbohydrates. Chips as one of the food products processed through the process of deep frying has a crispness as a characteristic of texture that is important to be controlled. The research method is descriptive with chemical test and organoleptic test. The purpose of this study is to study the addition of fish meat lemadang on the quality of cassava chips. The results stated that the high water content will affect the color, texture and taste of cassava chips, the high ash content affect the crispy texture of cassava chips, the high free fatty acid (FFA) give effect on the taste of cassava chips.

Keywords: cassava, chemical test, organoleptic test

\section{PENDAHULUAN}

Keripik sebagai salah satu produk pangan yang diolah melalui proses penggorengan rendam memiliki kerenyahan sebagai karakteristik tekstur yang penting untuk dikontrol [1]. Beberapa studi dan upaya telah dilakukan untuk meningkatkan kerenyahan keripik, misalnya dengan mengontrol parameter proses pengolahan berupa komposisi kimia bahan, dimensi bahan, serta suhu dan jenis minyak yang digunakan dalam penggorengan [2][3], maupun dengan memberikan perlakuan pendahuluan sebelum penggorengan berupa perendaman irisan bahan dalam larutan yang mengandung kation [4].

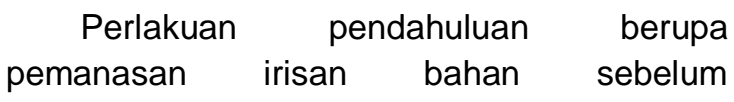
penggorengan merupakan cara yang belum populer tetapi berpotensi mempengaruhi kerenyahan dari keripik yang dihasilkan [5]. Para peneliti setuju bahwa kerenyahan disebabkan oleh karakteristik struktural makanan. Struktur poros menjadi faktor penting penentu kerenyahan [2][6]. Perlakuan pendahuluan terhadap irisan bahan sebelum penggorengan dimaksudkan untuk membantu pelonggaran jaringan dalam mempersiapkan struktur poros bahan. Proses pemanasan irisan bahan sebelum penggorengan diduga berperan dalam pelonggaran jaringan melalui mekanisme gelatinisasi pati, penurunan adhesifitas sel, serta pembebasan substansi penyusun jaringan ke medium [7][5].

Ubi Kayu (Manihot utilisima) banyak ditanam di Indonesia karena mampu beradaptasi dengan iklim tropis di Indonesia. Kandungan zat gizi yang paling banyak terdapat adalah karbohidrat yang merupakan sumber pati. Kandungan karbohidrat pada singkong adalah $34,7 \%$ [8][9].

\section{TUJUAN}

Tujuan dari penelitian ini adalah mempelajari penambahan daging ikan lemadang pada mutu keripik ubi kayu. 


\section{BAHAN DAN METODE}

Bahan yang digunakan antara lain ubi kayu, garam halus, ikan berdaging putih (ikan lemadang), bawang putih, minyak goreng. Alat yang dipakai diantaranya panci kukus, penggiling, pisau, roller, wajan penggorengan, kompor gas.

\section{METODE}

Penelitian ini dilakukan dengan metode deskriptif. Penggunaan Ubi kayu dengan ikan memakai perbandingan. Perlakuan $\mathrm{K}_{0}=$ tanpa ikan; $\mathrm{K}_{1}=$ ikan $0.5 \% ; \mathrm{K}_{2}=$ ikan $1 \% ; \mathrm{K}_{3}=$ ikan $2 \% ; K_{4}=i k a n 2,5 \%$. Besarnya perbandingan yaitu 100:0 ; 99,5:0,5 ; 99:1 ; 98:2 ; dan $97,5: 2,5$. Penambahan bumbu konstant antara lain garam $1 \mathrm{~g}$ dan bawang putih $1 \mathrm{~g}$.

Ubi kayu dikupas kulitnya lalu dicuci bersih dengan air mengalir. Kemudian ubi kayu diparut dan ditambahkan bumbu-bumbu dan ikan. Penambahan ikan mengikuti besarnya jumlah perbandingan yaitu $0.5 \%$, $1 \%, \quad 2 \%, \quad 2,5 \%$. Kemudian adonan dihomogenkan dan dicetak berbentuk silinder. Setelah itu dikukus $\pm 10-15$ menit dan didinginkan. Hasil kukusan dipotong dengan ketebalan $0,1-0,2 \mathrm{~cm}$. Selanjutnya dikeringkan dalam oven pada suhu $50-55^{\circ} \mathrm{C}$ selama 48jam, kripik siap digoreng.

\section{Analisis kriteria Uji Keadaan [10]}

Kriteria uji keadaan dalam SNI 01-43051996 keripik ubi kayu menjelaskan bahwa keadaan warna (normal), rasa (khas) dan tekstur (renyah).

Kriteria uji keadaan dalam SNI 01-43051996 keripik ubi kayu dipadukan dengan uji organoleptik dengan kriteria sebagai berikut:

a) Kriteria keadaan warna keripik tidak normal (1), agak normal (2), normal (3), sangat normal (4).

b) Kriteria keadaan rasa keripik tidak khas (1), agak khas (2), khas (3), sangat khas (4).

c) Kriteria keadaan tekstur keripik tidak renyah (1), agak renyah (2), renyah (3), sangat renyah (4).

Analisis Kadar Air, Abu, Asam Lemak Bebas (FFA) Keripik [11]

Analisis kimia berupa kadar air, abu, asam lemak bebas (FFA). Yang memberikan kerenyahan terbaik dan kontrol dilakukan untuk melihat ada atau tidaknya keterkaitan perbedaan komposisi kimia keripik antar perlakuan terhadap kerenyahan.

\section{HASIL DAN PEMBAHASAN}

Beberapa pengujian yang dilakukan pada keripik ubi kayu antara lain kadar air, kadar abu, FFA dan uji organoleptik (warna, rasa, tekstur), dilihat pada Tabel 1 dan 2.

Tabel 1. Hasil uji kimia ubi kayu

\begin{tabular}{c|c|c|c|c}
\hline \multirow{2}{*}{$\begin{array}{c}\text { Bahan } \\
\text { Baku }\end{array}$} & \multirow{2}{*}{ Perlakuan } & \multicolumn{3}{|c}{ Parameter Pengujian } \\
\cline { 3 - 5 } & $\begin{array}{c}\text { Kadar } \\
\text { Air (\%) }\end{array}$ & $\begin{array}{c}\text { Kadar } \\
\text { Abu(\%) }\end{array}$ & FFA(\%) \\
\hline \multirow{2}{*}{ Kbi } & $\mathrm{K}_{0}$ & 2.98 & 2.10 & 0.70 \\
\cline { 2 - 5 } & $\mathrm{K}_{1}$ & 3.46 & 2.24 & 0.64 \\
\cline { 2 - 5 } & $\mathrm{K}_{2}$ & 3.23 & 2.27 & 0.61 \\
\cline { 2 - 5 } & $\mathrm{K}_{3}$ & 3.19 & 2.30 & 0.59 \\
\cline { 2 - 5 } & $\mathrm{K}_{4}$ & 3.09 & 2.36 & 0.50 \\
\cline { 2 - 5 } & \multicolumn{4}{|l}{} \\
\cline { 2 - 5 } & \multicolumn{3}{|l}{} \\
\hline
\end{tabular}

Kadar air merupakan faktor penting yang berpengaruh terhadap kerenyahan. Kadar air keripik ubi kayu dengan perlakuan penambahan daging ikan lemadang $\mathrm{K}_{1}$ $(3,46 \%)$ lebih tinggi dibandingkan kontrol $\mathrm{K}_{0}$ (tanpa ikan) 2,98\%, hal ini disebabkan karena perlakuan pengukusan meningkatkan kadar air awal irisan singkong sebelum digoreng. Semakin perlakuan ikan ditambah $\mathrm{K}_{4}(3,09 \%)$ dan kandungan air dari ubi kayu dan air akan menguap saat terjadi proses penggorengan sehingga kerenyahan keripik ubi kayu ini menurun. Hasil penelitian kadar air ini masih di bawah standar SNI keripik ubi kayu yaitu maximum $6,0 \%$. Keripik ubi kayu ini layak di konsumsi. [12] Kadar air produk yang lebih tinggi menghasilkan kerenyahan yang lebih rendah.

Kadar abu merupakan faktor penting yang berpengaruh terhadap kualitas produk yang dibuat. Kadar abu keripik ubi kayu dalam penelitian ini dari perlakuan $\mathrm{K}_{1,2,3,4}$ dengan menambahkan ikan 0,5\%-2,5\% memiliki nilai $2,26 \%-2,36 \%$ lebih tinggi dari perlakuan kontrol $\mathrm{K}_{0}(2,10 \%)$ dan belum melebihi standar SNI keripik ubi kayu yaitu maksimum 2,5\%. Hal ini diduga pada saat ubi kayu dilakukan pengupasan, pencucian, pemarutan, penjemuran, penambahan ikan, pengukusan, dan penggorengan dilakukan sangat higienis dengan memakai air bersih, minyak baru, alat 
kukus steril sehingga produk yang dihasilkan layak untuk dikonsumsi.

Kadar asam lemak bebas (\%FFA) merupakan proses oksidasi dan hidrolisa enzim selama penyimpanan dan pengolahan. Berdasarkan SNI Keripik ubi kayu nilai kadar FFA (maksimum 0,7\%), perlakuan kontrol $\left(\mathrm{K}_{0}=\operatorname{tanpa} i k a n: 0,70 \%\right)$ hal ini dikarenakan pada proses penggorengan keripik ubi kayu tidak menggunakan minyak goreng kemasan melainkan menggunakan minyak goreng curah dan digunakan berulang kali penggorengan, serta penggunaan suhu yang tinggi pada saat penggorengan dengan waktu yang lama. Sehingga keripik yang dihasilkan akan cepat tengik. Kaitan FFA/asam lemak bebas dengan ketengikan yaitu karena kerusakan lemak yang utama adalah timbulnya bau tengik yang disebut proses ketengikan. Hal ini disebabkan oleh oksidasi. Oksidasi dimulai dengan pembentukan radikal bebas. Molekul-molekul lemak yang mengandung radikal asam lemak tak jenuh mengalami oksidasi dan menjadi tengik. Berbeda dengan yang menambahkan ikan perlakuan $\mathrm{K}_{1,2,3,4}(0,5 \%-2,5 \%)$ memiliki nilai FFA antara $0,64 \%-0,50 \%$ sehingga mutu produk keripik ubi kayu yang dihasilkan layak dikonsumsi.

\section{Analisis Organoleptik (Warna, Tekstur, Rasa)}

Tabel 2. Hasil uji organoleptik ubi kayu

\begin{tabular}{ccccc}
\hline $\begin{array}{c}\text { Bahan } \\
\text { Baku }\end{array}$ & \multirow{2}{*}{ Perlakuan } & \multicolumn{3}{c}{ Parameter Organoleptik } \\
\cline { 3 - 5 } & & Warna & Tekstur & Rasa \\
\hline Ubi & $\mathrm{K}_{0}$ & 2.43 & 2.93 & 2.68 \\
Kayu & $\mathrm{K}_{1}$ & 1.81 & 3.0 & 2.25 \\
& $\mathrm{~K}_{2}$ & 2.1 & 2.93 & 2.25 \\
& $\mathrm{~K}_{3}$ & 2.25 & 2.93 & 2.25 \\
& $\mathrm{~K}_{4}$ & 2.06 & 2.75 & 1.56
\end{tabular}

Hasil penelitian tentang uji organoleptik warna keripik ubi kayu bahwa perlakuan $\mathrm{K}_{1,2,3,4}$ $(1,81 \%-2,06 \%)$ memiliki nilai lebih kecil dari perlakuan kontrol $\mathrm{K}_{0}(2,43 \%)$ kriteria warna keripik tidak normal-agak normal. Tidak cerahnya warna keripik ubi kayu dipengaruhi oleh nilai kadar air dalam penelitian ini $\mathrm{K}_{1}$ $(3,46 \%)$ lebih tinggi dibandingkan kontrol $\mathrm{K}_{0}$ (tanpa ikan) 2,98\%, hal ini disebabkan karena perlakuan pengukusan meningkatkan kadar air awal irisan singkong sebelum digoreng. Adanya protein (gugus amina primer) dengan gula pereduksi yang berasal dari karbohidrat pada suhu tinggi akan menghasilkan bahan berwarna cokelat yang disebut sebagai reaksi Maillard atau pencoklatan non enzim [13].

Hasil penelitian nilai uji organoleptik tekstur keripik ubi kayu bahwa nilai perlakuan $\mathrm{K}_{0,2,3,4}$ memperoleh kriteria agak renyah dan $\mathrm{K}_{1}$ mendapat kriteria renyah. Nilai suka pada tekstur keripik ubi kayu dalam penelitian ini dipengaruhi oleh nilai kadar air $\mathrm{K}_{1}$ yang karena kadar air ini fungsinya menjaga tekstur produk keripik ubi kayu ini tetap renyah, dan kadar abu mempengaruhi tekstur keripik ubi kayu yang berperan terhadap kualitas produk dan juga pengaruh kadar asam lemak bebas dari hasil penelitian ini bahwa belum terjadi proses oksidasi yang berdampak pada menurunnya kerenyahan tekstur keripik ubi kayu.

Hasil penelitian dari pengujian organoleptik kriteria rasa bahwa $\mathrm{K}_{0}$ (kontrol=tanpa ikan) memberikan nilai tertinggi pada rasa keripik ubi kayu yaitu agak khas, ini juga dialami oleh perlakuan $\mathrm{K}_{1,2,3,4}$ hasil yang didapat adalah dari kriteria rasa keripik agak khas-tidak khas. Hal ini dipengaruhi oleh tingginya nilai kadar air $\mathrm{K}_{1}(3,46 \%)$ lebih tinggi dibandingkan kontrol $\mathrm{K}_{0}$ (tanpa ikan) 2,98\%, hal ini disebabkan karena perlakuan pengukusan meningkatkan kadar air awal irisan singkong sebelum digoreng.

Kadar asam lemak bebas (FFA) berpengaruh pada rasa keripik ubi kayu bahwa perlakuan kontrol ( $\mathrm{K}_{0}=$ tanpa ikan: $0,70 \%$ ) hal ini dikarenakan pada proses penggorengan keripik ubi kayu tidak menggunakan minyak goreng kemasan melainkan menggunakan minyak goreng curah dan digunakan berulang kali penggorengan, serta penggunaan suhu yang tinggi pada saat penggorengan dengan waktu yang lama. Sehingga keripik yang dihasilkan akan cepat tengik.

\section{KESIMPULAN}

Semakin tinggi kadar air akan mempengaruhi warna, tekstur dan rasa keripik ubi kayu, semakin tinggi kadar abu mempengaruhi nilai tekstur renyah keripik ubi kayu dan rendahnya kadar asam lemak bebas (FFA) berpengaruh pada rasa dari keripik ubi kayu. 


\section{DAFTAR PUSTAKA}

[1]. Thanatuksorn $P$, Kajiwara $K$, Suzuki $T$. 2007. Characterization of deep-fat frying in a wheat flour-water mixture model using a state diagram. J Sci Food Agric 87: 2648-2656.

[2]. Visser J. 2007. Development and loss of crispness during the frying of French fries.

http://www.agfdt.de/loads/kt07/visser.p df [23 Februari 2014].

[3]. Kita A, Lisin'ska G, Gołubowska G. 2007. The effects of oils and frying temperatures on the texture and fat content of potato crisps. Food Chem 102: 1-5.

[4]. Pedreschi F, Moyano P, Santis N, Pedreschi R. 2007. Physical properties of pre-treated potato chips. J Food Eng 79: 1474-1482.

[5]. Grizotto R, De Menezes HC. 2002. Effect of cooking on the crispness of cassava chips. J Food Sci 67:pp 1219-1223.

[6]. Saeleaw M, Schleining G. 2011. Effect of frying parameters on crispiness and sound emission of cassava crackers. J Food Eng 103: 229- 236.

[7]. Andersson A, Gekas V, Lind I, Oliveira F, Oste R. 1994. Effect of preheating on potato texture. $\mathrm{Cr}$ Rev Food Sci 34: 229-251.

[8]. Direktorat Gizi. 2013. Daftar Komposisi Bahan Makanan. Bhatara, Jakarta.

[9]. Astawan M, Widowati S. 2005. Evaluasi Mutu Gizi dan Indeks Glikemik Ubi Jalar sebagai dasar Pengembangan Pangan Fungsional. Laporan Hasil Penelitian RUSNAS Diversifikasi Pangan Pokok. Bogor: Institut Pertanian Bogor.

[10]. BSN. SNI 01-4306-1996. Keripik Ubi Kayu. Jakarta

[11]. [AOAC] Association of Official Analytical Chemist. 2006. Official Methods of Analysis of The Association of Official Analytical Chemist. Washington DC.

[12]. Luyten $H$, van Vliet T. 2006. Acoustic emission, fracture behavior and morphology of dry crispy foods: a discussion article. J Texture Stud 37: 221-240.
[13]. Winarno, F.G. 2004. Kimia Pangan dan Gizi. PT.Gramedia Pustaka Utama. Jakarta. 